\title{
DE KATE FIELD A MARTHA GELLHORN, BUSCANDO UN ESPACIO PROPIO
}

\author{
Mercedes Caballer Dondarza \\ Suffolk University, Madrid
}

\section{RESUMEN}

La prensa favoreció la publicación de los relatos y crónicas de viaje sobre España en el siglo XIX en Estados Unidos y Europa. Estos evolucionaron desde la visión romántica, exótica y oscura del bandolero hasta otra más informada y realista a finales del siglo XIX. Las escritoras más atrevidas aprovecharon la mejora de los medios de comunicación para alcanzar al gran público; así lo hizo Kate Field, cuya visita a España refleja su libro Ten Days in Spain. Ya en el siglo xx, Martha Gellhorn se atreve con las crónicas sobre la Guerra Civil desde Madrid. Analizar cómo narran esta aventura y lo que constituye para crear su propio espacio e identidad nos puede ofrecer una nueva perspectiva desde la que considerar el relato de viajes norteamericano sobre España.

PAlabras Clave: literatura de viajes, crónicas de viaje femeninas, geografías imaginativas, espacios propios, identidad.

\author{
FROM KATE FIELD TO MARTHA GELLHORN, \\ THE SEARCH FOR A SPACE OF THEIR OWN
}

\section{Abstract}

During the nineteenth century the press promoted the publication of travel accounts and essays on Spain in the United States and Europe. Towards the end of the century, these texts evolved from the romantic, exotic and dark image of the bandit to one more informed and realistic. The boldest women writers took advantage of the various improvements in the press to reach the general public, as Kate Field did with the account of her journey abroad, Ten Days in Spain. In the twentieth century, Martha Gellhorn dared to write journalistic chronicles about the Spanish Civil War from Madrid. Analysing their adventures and what these entail in the creation of a space and an identity of their own may, can offer a new perspective from which to consider American travel writing on Spain.

KEYwORDs: travel literature, female travel accounts, imaginative geographies, spaces of one's own, identity. 
La sorprendente proliferación de relatos de viajes debidos a manos femeninas durante el siglo XIX surge en un ambiente que favorece poco la actividad literaria de las mujeres, al menos en el espacio público. La disparidad existente entre el avance tecnológico y la ideología aún conservadora de la sociedad, tanto en Europa como en Estados Unidos, se ve favorecida por la publicación de sus ensayos y relatos de viaje en la prensa, que en este último país disfruta de un período de auge a partir de 1830, gracias a medidas económicas y postales. Así, consiguen la atención del sector público en general, contribuyen a transformar la opinión reacia de la sociedad de la época y logran, con lentitud, el reconocimiento del sector intelectual, masculino en su mayor parte. Tanto es así que ya en 1848 la Blackwood's Edinburgh Magazine en su artículo "Modern Tourism» describe esta nueva clase de aventurera como a una "professional tourist; the woman who runs abroad to forage for publication; reimports her baggage, bursting with a periodical gathering of nonsense» (citado en Oliveira 2013: 180). A pesar de múltiples críticas y obstáculos, gradualmente se irían normalizando estos nuevos hitos en el desarrollo profesional de las mujeres.

Las viajeras muestran su habilidad para moverse solas, aunque conservando esa condición de damas que requiere la sociedad de la época, para lo cual se acompańan de alguna amiga o sirviente, o de un ayudante, como el ficticio Blinker del que habla Kate Field, al igual que hiciera su antecesor, Irving, con la voz de su inseparable cicerone Mateo Ximénez. Asimismo, se mueven en espacios públicos en su mayoría: cafeterías, estaciones y trenes, hoteles y tiendas, entrevistando a un político, como hace Kate Field, o visitando las trincheras y a los heridos, como hará Martha Gellhorn. Son autoras que transgreden las limitaciones del espacio privado, no solo de su propio país sino de otro continente, y aquellas que podían establecerse para una dama de su época. Así, se encuentran en lo que recientemente ha considerado la crítica como mujeres «in transit» (Gómez Reus \& Gifford 2013), a punto de cruzar el umbral que las separa de las experiencias que labrarán su identidad, o, al menos, reflejarán la propia en el espejo de lo nuevo, lo desconocido. Será al volver a su país, a la sociedad que las limita o las define, cuando tengan que decidir cómo adaptarse o no al punto de partida:

These texts that originated from their author's own experiences while being in transit throw a valuable sidelight on the manner in which our subjectivity and cultural productions are shaped by our ways of interacting with space. At the same time, they also illustrate the close relationship that may exist between women's use of space and politics, and between their mobility and aesthetics (Gómez Reus \& Gifford 2013: 6-7).

En la búsqueda de ese espacio desde el que asumir su propia identidad en relación con el otro, las autoras intentan distinguirse de autores anteriores y de las guías de viaje que ya proliferan en ese momento. Y entendemos espacio como algo en movimiento, que fluye y cambia gracias al «diverse range of social processes and human interventions, and a force that, in turn, influences, directs and delimits possibilities of action and ways of being human in the world» (Wegner 2002: 181). $\mathrm{O}$, tal como apunta Doreen Massey, «a product of interconnecting flows -of routes rather than roots» (citado en Creswell 2015: 88). 
Consideramos ese concepto de espacio como continuidad del de contacto que ya estableciera Mary Louise Pratt cuando afirmaba «a contact perspective emphasizes how subjects are constituted in and by their relations to each other. It treats the relations among colonizers and colonized, or travelers and 'travelees', not in terms of separateness or apartheid, but in terms of copresence, interaction, interlocking understandings and practices, often within radically asymmetrical relations of power» (1992: 7). Es decir, una concepción del espacio basada en la movilidad, la variedad y las interacciones, no en lo estrictamente fijo e inamovible.

Como ocurre con las dos autoras analizadas, ese espacio que fluye nos ofrece una visión diferente, más reducida, con más detalle de la cotidianeidad, incluso en tiempos de guerra. Y es precisamente durante el conflicto bélico cuando los objetos y los gestos de los personajes consiguen transmitir emociones propias de ese espacio en transición del que entra a formar parte la autora en cuestión. Estamos de acuerdo, por tanto, con la siguiente afirmación: «[M]any women concerned themselves with a smaller mapping of space; often their quests were less about opening new territories for their country and more about opening new spaces for themselves and their readers at home» (Kelley 2005: 358).

Escribir para un periódico no es una profesión admirada en ese momento, ni siquiera para sus compańeros, y menos en el caso de una mujer que tiene que acudir a las oficinas de un periódico o de una revista. La ficción, en cambio, permite permanecer en el ámbito privado del hogar, tal como apunta Valérie Fehlbaum:

If it was acceptable for ladies to send in accounts of social occasions, interviews of celebrities and works of fiction, all produced within the confines of the home, it was considered very unladylike to cross the threshold of the newspaper office itself, a bastion of male privilege, and even worse to engage in the liminal activity of investigative journalism as a reporter (2013: 61).

La prensa publica artículos para aprender a ser periodista y, específicamente, periodismo para mujeres. Incluso, la propia ficción se ocupa de personajes que lo son. Pero pronto se establecen distinciones entre aquellas escritoras que se dedican a lo doméstico, a escribir sobre la moda, las alfombras y las joyas, y las que se atreven a cruzar el océano con otros objetivos. Lo que en Estados Unidos se considera dentro de la normalidad no es así percibido en el Reino Unido, tal como se argumenta en un artículo anónimo («Women as Journalists by a Man Editor») publicado en 1890 en la revista Woman:

I am of course assuming that a woman's aspiration in journalism is limited to the work which is most congenial to her sex and habits. In America, lady journalists enjoy a somewhat wider range that at present they care to adventure upon in England, and editors send young women to break the record in globe-trotting, or commission them to personate thieves and lunatics, in order to furnish racy descriptions of the inner economy of prisons and mad-houses for the delectation of their readers. Work of this kind is hardly, however, what English ladies have in mind when they talk of Journalism for Women (citado en Fehlbaum 2017: 65). 
En cambio, la escritora Ella Hepworth Dixon en sus memorias contradice esa opinión cuando explica que en los años noventa del siglo diecinueve, "when she spent a winter Season in New York", ella misma era "prudent enough to conceal the fact that [she] had ever written for any journal. A 'newspaper woman', over there, had no social standing whatever» (1930: 100). La mujer periodista, difusora y escritora de noticias, podía paradójicamente convertirse en una figura invisible.

A pesar de esa percepción social, algunas se atreven a cruzar el océano, y aunque es difícil establecer el número exacto, Schriber (1995: xii) habla de ciento noventa y cinco libros de viaje publicados por escritoras americanas antes de 1900, de ellos más de cincuenta dedicados a Gran Bretańa y Europa. Al mismo tiempo, aparecen mil seiscientos cinco de autoría masculina. En particular, sobre España ven la luz más de cien libros entre Estados Unidos y Reino Unido antes de 1900, y, de esos, al menos quince lo hacen a manos femeninas (Serrano 1993). Es difícil establecer una comparación con las obras que publican autoras españolas en esa misma fecha, dada la falta de un índice al respecto. No obstante, considerando el epígrafe de viajes de la obra biobibliográfica de Simón Palmer (1991), se puede estimar en treinta y cuatro el número de relatos, solamente durante el siglo XIX, realizados por autoras españolas tanto del resto de Europa como de Sudamérica.

En este contexto, analizaremos los textos de estas autoras y su actitud ante un país y una cultura que ya se han descrito como exóticos y bárbaros en décadas anteriores y alrededor de los cuales gira una larga tradición de relatos de viajes. Nos centraremos en la actitud de dichas autoras al cruzar ese umbral hacia el otro, hacia lo desconocido, con el fin de analizar la continuidad de los estereotipos ya aparecidos con respecto a los españoles, su historia y su cultura. Veremos si adoptan una actitud imperialista, como reconocía Mary Louise Pratt, o realizan ese tránsito hacia el respeto por la nueva cultura. Pero, sobre todo, observaremos el reflejo de estas autoras en el espejo que constituye la cultura visitada, y si con él se conocen, exploran sus límites y encuentran su espacio y a sí mismas. Como apunta Joyce Kelley «the key to each text is not what each woman actually sees on her adventures but what the adventure becomes for her and how she chooses to present it» (2005: 359).

Considerando que muchos relatos de viaje se publican en prensa y que hay escasos estudios sobre periodistas como tales, o incluso corresponsales, incluimos aquí a Kate Field, la primera de la que tenemos noticias, que dispone además de su propio periódico. Su obra Ten Days in Spain tiene gran repercusión en Estados Unidos y muestra una actitud en transición entre la admiración romántica de Washington Irving y el estrecho contacto con la realidad de la calle que aporta Martha Gellhorn, la segunda autora escogida para este estudio. Audaz corresponsal que cubre la Guerra Civil española, Gellhorn, conocida por su relación con su amigo Hemingway, como ella lo denomina, compartió con él una parte muy corta de su larga y fructífera vida. Acompañando a ambas se conforma ese espacio en tránsito, cada vez más subjetivo, más cotidiano, más íntimo y más alejado del objeto exótico mostrado por autores anteriores. 


\section{KATE FIELD}

"A natural-born enthusiast», así describe Jane Nardin (1997: 439) a esta actriz, escritora, conferenciante, editora, periodista y activista, cuyas ideas sobre el abolicionismo le cuestan ser desheredada por su tío. Editora de su propio periódico, Kate Field's Washington, resulta ser una periodista intrépida que nos explica su objetivo al viajar a España de la forma siguiente:

[F]or what right had I to take up his valuable time, -I who had come to Spain solely to look at him, hear him talk if he would, and draw my own conclusions for my own satisfaction? I had not been sent on a mission by a great moral organ; I was not clothed in the garb of an interviewer. Impulse alone had impelled me (1875: 137-138).

Es su propia satisfacción la que la lleva a entrevistar al presidente de la República, Emilio Castelar, que lo será, como augura la propia Kate Field, por poco tiempo. Aunque menciona que este viaje se debe a un impulso propio, lo cierto es que, según recuerda Lilian Whiting, la idea ya se fraguó en una visita anterior a Londres:

Another element of destiny came just then into Kate's life. At a dinner-party she met Señor Moret, the Spanish Minister and his wife, the Señora, with Mademoiselle Gaetano and Monsieur Brosseau, the latter of whom assured her that he was a republican and wished to go to America. It was at this dinner that Miss Field, whose nature was as susceptible to an idea as tinder to a spark of fire, first conceived the thought of visiting Spain, and interviewing Emilio Castelar, the president of the Spanish Republic, whose political situation was at the time peculiarly interesting (1899: 310-311).

A lo largo de los nueve capítulos que contiene su obra, aparece este leitmotiv, la búsqueda de los republicanos. Ten Days in Spain será un gran éxito en Estados Unidos, ya que a su primera edición de 1875 le seguirán otras en 1886 y 1892, y la cuarta en 1898, probablemente provocada por el conflicto con Cuba en ese momento. Gary Scharnhorst, en su biografía literaria de la autora, apunta que dichas ediciones "were nearly as popular as her reports on Dickens and the shah. Louise Chandler Moulton praised them without stint: the narrative, she wrote, not only illustrates the mishaps and mistakes of travel with light of the kindliest and brightest humor, but it is also full of sagacious observation" (2008: 104). Tanto es así que, según Scharnhorst, gracias a la calidad de estos ensayos enviados desde Europa le ofrecen el puesto de corresponsal:

Her Newport friend James Parton, a popular biographer and the husband of the late Sara Payson Willis Parton (aka Fanny Fern), wrote to her, «I wonder if you know how welcome the readers of the 'The Tribune' are. Your initials and all that goes before them [...] All your letters from Europe last year, -your Spanish, especially [...] delighted me, and I feel grateful to you for them. I hope you will regularly join 'The Tribune' as its writing-whenever-you-feel-like-it-correspondent, at a salary that will cheer and not inebriate you» (2008: 104). 
No obstante, la crítica sobre obras femeninas de viaje denuncia que «it was good graphic journalism, and it was a pity she felt obliged to dilute it with travelogue whimsy" (Woodward 1971: 211). Para Field, al igual que para otras escritoras que también mandan crónicas desde el Viejo Mundo, la frontera entre el periodismo y los libros de viajes a menudo se vislumbra borrosa, permitiendo atrevidas intersecciones literarias.

Como otras obras, la crónica viajera que Field ofrece en Ten Days in Spain constituye un recorrido circular que comienza y acaba en los Pirineos, con una estructura lineal y cronológica. Considerada hoy en día como «nonfiction novel», nos recuerda Scharnhorst, no se puede considerar propiamente periodismo, «but polished essays written months after the events they purport to describe» (2008: 103). Field comienza esta recopilación sobre su aventura a España con una crítica ácida hacia un sector de la población, muy viajado, al que denomina «Superior Being». Emplea la actitud de sus amigos franceses que le han recomendado Biarritz para hacer una crítica de la actitud de un sector de la sociedad en boga:

Whatever place you have never seen is precisely the place set down as the earthly paradise by those Superior Beings who have been everywhere. [...] There is an aggressiveness, an undisguised contempt, a pitying patronage about the Superior Being who insists upon perennially sitting in Nile mud, and calling you from the antipodes to admire his poses, that makes you thirst for human blood. The greatest trial of Society is not being able to resent these underhand attacks upon one's self-esteem. [...] I never make a present of my opinions. I am always paid for them (1875: 14-16).

Field, como harán otras autoras, quiere distinguirse de viajeros anteriores cuando afirma «I am not Murray. I don't propose to furnish information that will be of slightest use to the most inexperienced traveller. All I shall relate is what stuck to me like burrs after the guide had poured the entire Escorial into my aching ears» (1875: 164). A pesar de esa afirmación, hace los mismos recorridos que otros turistas, va a los toros, y pretende comprar una mantilla, para lo cual pregunta a mujeres españolas, quienes le aconsejan regatear. Y es que, debido a la proliferación de guías de viaje, al igual que ocurre con autoras españolas como Emilia Pardo Bazán, hacen énfasis en la importancia de su propia impresión, de una manera subjetiva.

Ya desde el principio, la autora se queja de los obstáculos con los que se va encontrando, el primero al salir del barco que la lleva desde el sur de Francia hasta Santander. Una epidemia de cólera le impide sacar el baúl de la nave, aunque sí su ropa. Asimismo, tan pronto como llega a Madrid comienzan las críticas:

Without the customary warning of environs, without premonitions of human existence, I found myself shot into the capital of Spain, which seems to have been dropped into the middle of a plain twenty-four hundred feet above the level of the sea, for no better reason than incongruity. The eternal fitness of things did not preside over the founding of Madrid (1875: 103). 
Hace así referencia a la crítica de Washington Irving sobre la capital. Una vez sentada en un café, se pregunta: "What had I come for? To look Spain in the face, and see Castelar» (1875: 105). Y elige al mismo dueño del hotel en el que se aloja, que es italiano, para recabar su opinión sobre el país:

The Spaniards are ignorant and cruel. They are not republican. Nobody that I see wants a republic. Everybody wants something else; but, as all are quarrelling among themselves, Señor Castelar maintains his position. He is a good man. He writes fine books, and makes beautiful speeches. But the end of it will be that we shall have a king. I am sick of it all, and I'd like to go to America, where people are intelligent and the poor have a chance to rise (1875: 106).

No parece que estas apreciaciones sean pura coincidencia. Más adelante, se va encontrando con algunos americanos y confirma lo siguiente: «To discover people is far more delightful than to discover things. If more money were spent on human and less on geographical explorations, the world would be a deal happier» (1875: 106-107). Una crítica evidente a sus colegas masculinos y a los relatos de viaje que han publicado en relación con grandes espacios que explorar y con grandes monumentos que describir.

Durante su periplo periodístico por Espańa, Field no quiso evitar de ningún modo la fiesta nacional por antonomasia, las corridas de toros, aunque sus razones para visitar lo que más tarde definirá como un fenómeno brutal son, más que estéticas, de índole variada: «But as American clergymen visiting Spain always attend bull-fights, making the self-sacrifice in order to warn their flocks against them, I had no scruples. I might assert that I was actuated by the noblest motives; but I think my real reasons were curiosity and a desire to see Spain in her glory» (1875: 107). Cualquier situación es una excusa válida para sus duras críticas sobre la sociedad y la política, a veces salpicadas de sarcasmo e ironía: «This is the country that once ruled the world, the country to which America owes its discovery! Is anything as incredible as history?» (1875: 100). De nuevo, en su camino hacia la plaza, afirma que si los españoles se pusieran de acuerdo en cuanto a la política como lo hacen para una corrida de toros, todo sería mucho mejor. Y continúa: «Alas! unanimity among Spaniards means butchery-either of horses, bulls, Cuban students, or Cuban patriots. The taste of the Inquisition still remains in their mouths» (1875: 108). En la plaza de toros encuentra a dos americanos que le ofrecen dos voces muy convenientes para relatar sus opiniones políticas de nuevo: uno es neoyorquino, el otro oriundo de Rhode-Island. Establece con esa denominación geográfica las características de sus acompañantes cuando nos dice «I felt proud of my company. They did credit to their country and their sex. Their sex was not mine. If the eyes of America had fallen upon them, she might have exclaimed, as did Cornelia under similar circumstances, 'These are my jewels'” (1875: 109).

$\mathrm{Al}$ igual que harán otras autoras, también españolas, se servirá de la opinión de otros personajes que va encontrando en su camino, no sabemos si ficticios o no, como sí lo es el personaje de Blinker, que la acompaña en el viaje. A un vendedor de fotografías atribuye la siguiente opinión, por desgracia muy actual: «You see every- 
body is poor here, and everybody wants to live off the government without doing any work. So men stay in office until they rob the treasury as much as they dare, and then retire on a personal misunderstanding» (1875: 150). A su favor podemos señalar que ofrece también la opinión de algunas mujeres a las que pregunta por sus temas políticos en el tren que la lleva de camino a Madrid. El dilema que Field les plantea reside en elegir entre república, monarquía legitimista o carlismo:

«You are not republicans?»

«O no; nor any one else», replied the most voluble of the señoras.

«Are you in favor of Don Carlos?»

«Not at all. It is a great trial to be torn to pieces by civil war, but we are obliged to endure it. The best Spaniards are Alphonsists. The Queen we do not want. She has disgraced us; but her son is our legitimate sovereign. Unfortunately, he is very young. We fear a regency, and so accept the present government» (1875: 94-95).

Y más tarde, en otro episodio del viaje, nos ofrece su imagen como la de una protagonista: «I was consorting with smugglers! [...] and I began to feel like the heroine in a melodrama who innnocently assists at the plotting of heavy villains» (1875: 237). Así, apelando al sentido del riesgo, dota a la narración de un cierto grado de emoción escénica potencialmente del gusto de los lectores.

Su actitud ante los lugares que visita es de altanería. Define El Escorial como "the monstruos conception of that tyrant, monk, and hypochondriac, Philip II» (1875: 164). A la mañana siguiente es Toledo la ciudad que sufre sus duros comentarios; estos le permiten distinguirse de ese «otro país» bárbaro y su pertenencia al continente americano, como si aquel estuviera libre de lo que describe a continuación: «I never felt so thankful for America as while walking through those narrow Toledan streets, every stone of which could tell tales of bloodshed and violence» (1875: 179). Casualmente, los toros de la corrida a la que asiste pertenecen a un duque descendiente de Cristóbal Colón, excusa de nuevo perfecta para que ella apunte: "We prefer America to bull-fights; Spaniards prefer bull-fights to America» (1875: 113-114). Los símiles se van repitiendo con respecto a los toros y la política, y sus comentarios son hirientes: "Sooner will Spain voluntarily free her slaves, and grant Cuban independence, that connive at the suppression of her peculiar institution" (1875: 125). Y con gran facilidad consigue la autora pasar de ese tipo de críticas a la moda parisina que pasean las mujeres por el «miniature Hyde Park», es decir, por el Retiro, el mayor parque de la capital, donde apunta: «the purest classical profile known to me is that of a New England woman. Mixture of races seems to produce the characteristic beauties of all». Y por fin la comida: «There is no country in Europe with so horrible a cuisine as Spain. This is the dominant reason why self-respecting travellers carefullly avoid it» (1875: 128). Sus últimas palabras harán referencia a las soberanas españolas: «And when Americans revile the second Isabella, would it not be well to recall the first, the sovereign to whose generosity we owe the discovery of our continent? If a woman lost Spain, a woman found America, and for her sake, as well as for humanity's, I cry from my heart, -'St. Jago and forward Spain!'» (1875: 277). 
Ha sido difícil encontrar una palabra amable de Kate Field hacia ese otro aún considerado bárbaro, al que describe con ironía y sarcasmo. Como se puede apreciar, muchos episodios de Ten Days in Spain presentan en gran medida esa actitud altiva de la viajera estadounidense, que desprecia y critica la cultura visitada, creando un espacio propio poco amable. Una actitud que continúa en su viaje de vuelta hacia los Pirineos, cuando ridiculiza la ignorancia de las mujeres españolas que la acompañan en el mismo compartimento del tren, pues ella, una americana, les sirve de fuente de información sobre su propio país.

\section{MARTHA GELLHORN}

Martha Gellhorn cuenta cómo, durante el verano de 1936, mientras estaba investigando en la ciudad de Stuttgart para escribir una novela sobre jóvenes pacifistas en el sur de Francia, comienza a oír hablar sobre enfrentamientos en España. Informada sobre lo ocurrido, decide viajar a nuestro país, dejando de ser pacifista ella misma y convirtiéndose en antifascista (Gellhorn 1988: 13-14). Recuerda que en el invierno de 1937 las democracias occidentales habían proclamado la no intervención en el conflicto y se necesitaban papeles para atravesar la frontera; a pesar de todo consigue entrar en el país, llegando a Barcelona, donde en ese momento todo era gratis. Sin embargo, en una carta que escribe el 8 de enero a su amiga Mrs. Roosevelt, además de informarle de su estancia en Key West y de sus charlas con Hemingway, le expresa su opinión sobre el conflicto con las siguientes palabras: «If the madman Hitler really sends two divisions to Spain my bet is that the war is nearer than even the pessimist thought» (citado en Moorehead 2006: 45).

Para este trabajo emplearemos los artículos que Gellhorn manda a Collier's Weekly entre julio de 1937 y noviembre de 1938, en las dos visitas que realiza a España, con los títulos de su preferencia que ofrece en la sección titulada «The War in Spain» de su obra The Face of War (1959). En dicha sección agradece las facilidades que le da la revista para iniciar, casi accidentalmente, su carrera como corresponsal de guerra, aunque también explica que lo único malo de dicha colaboración son los títulos que la revista adjudica a sus ensayos. No obstante, son ocho años de colaboración durante los cuales se le permite viajar donde ella quiere y escribir sobre lo que ve, tal como le aconseja su amigo, Hemingway. Eso es lo que hace, en efecto, cuando describe los bombardeos que escucha y la espera rutinaria de los ciudadanos ante los ataques fascistas a la capital, como describe en "High Explosive for Everyone», escrito en julio de 1937:

At first the shells went over: you could hear the thud as they left the Fascist's guns, a sort of groaning cough; then you heard them fluttering toward you. As they came closer the sound went faster and straighter and sharper and then, very fast, you heard the great booming noise when they hit. [...] You could only wait. All over Madrid, for fifteen days now, people had been waiting. You waited for the shelling to start, and for it to end, and for it to start again. It came from three directions, at any time without warning and without purpose (1988: 19-20). 
Gellhorn describe las mujeres y niños que pasan por la calle con frases que intentan sugerir una aparente normalidad: "an old woman with a market basket on her arm hurried down a side street. And two boys came around the corner, arm in arm, singing» (1993: 20). Asimismo, relata cómo se sienten los que van a trabajar a pesar de los bombardeos: "'Well', he said, 'I think that is all. I have work to do. I am a serious man. I cannot spend my time waiting for shells. Salud', he said, and walked out calmly into the street, and calmly crossed it» (1988: 20). A pesar de los estragos de la guerra, uno de sus objetivos es reflejar la vida diaria, que sigue como si nada hubiera pasado:

In a café which was hit in the morning, where three men were killed sitting at a table reading their morning papers and drinking coffee, the clients came back in the afternoon. You went to Chicote's bar at the end of the day, walking up the street which was No Man's Land, where you could hear the shells whistling even when there was silence, and the bar was crowded as always. On the way you had passed a dead horse and a very dead mule, chopped with shell fragments, and you had passed crisscrossing trails of human blood on the pavement (1988: 21).

En otro artículo, «The Besieged City», escrito en noviembre de 1937, Gellhorn narra con un gran sentido práctico, incluso con cierto sentido del humor, la tragedia que les rodea en Madrid:

Finally, it was someone's birthday, or a national holiday (and still cold and nothing happening, only the rain and the rumors), so we decided to have a party. [...] There were always funny people in the trenches, new faces, always something to talk about. So we strolled to University City and Usera, to the Parque del Oeste, to those trenches that are a part of the city and that we knew so well. No matter how often you do it, it is surprising just to walk to war, easily, from your own bedroom where you have been reading a detective story or a life of Byron, or listening to the phonograph, or chatting with your friends (1988: 27, 32).

Teniendo en cuenta todo lo vivido, al final se pregunta, consciente de lo que ocurrirá cuando deje el país, cómo podrá explicar algunas de las cosas de las que ha sido testigo de primera mano:

How it is going to be possible ever to explain what this is really like? All you can say is, «This happened; that happened; he did this, she did that». But this does not tell how the land looks on the way to the Guadarrama, the smooth brown land, with olive trees and scrub oak growing beside the dry stream beds, and the handsome mountains curving against the sky. [...] And there is no time to write of the school where the children were making little houses of clay, and dolls from cardboard [...] How can I explain that you feel safe at this war, knowing that the people around you are good people? (1988: 36).

Son escasas las ocasiones en las que Gellhorn describe la belleza del paisaje que rodea la ciudad, a pesar de tratarse de un ambiente tremendamente hostil. A diferencia de su predecesora, consigue transmitir una gran emoción a través de los 
pequeños detalles de la vida cotidiana de esos otros que encuentra a su paso. Con los años, según observa en la introducción que en 1959 escribe para la primera edición de The Face of War, recuerda que "when I was young, I believed in the perfectibility of man, and in progress, and thought of journalism as a guiding light» (Gellhorn 1988: 1). Más tarde, tras haber visto otros conflictos bélicos, su opinión sobre el periodismo va cambiando:

After the war in Finland, I thought of journalism as a passport. [...] Journalism at its best and most effective is education. Journalism is a means; and I now think that the act of keeping the record straight is valuable in itself. Serious, careful, honest journalism is essential not because it is a guiding light but because it is a form of honourable behaviour, involving a reporter and a reader. I am no longer a jounalist; like all other private citizens, the only record I have to keep straight is my own $(1988: 2,3)$.

Cuando se refiere a su forma de escribir, en la introducción que escribe en 1959 , recuerda que «(I) wrote very fast, as I had to; and I was always afraid that I would forget the exact sound, smell, words, gestures which were special to this moment and this place. I hope I learned to write a bit better as the years passed. The point of these articles is that they are true; they tell what I saw» (1988: 6). Es decir, recuerda a sus lectores que en su labor periodística la escritura y su estilo han estado ante todo al servicio de la verdad.

En marzo de 1937, de camino a España en barco, muestra su vulnerabilidad cuando afirma «only Spain worries me; I am nervous of not understanding anything, getting side-tracked somewhere and confused in my thinking. That would be pretty grim. No use worrying about it in advance» (citado en Moorehead 2006: 51). A su llegada, después de su paso por Barcelona, es su amigo (Hemingway) quien le dice que escriba lo que ve en Madrid. Al aceptar su primer artículo la revista Collier's Weekly, en Nueva York, se da cuenta de que se ha convertido en corresponsal, como le ocurriera a Kate Field. Antes de llegar, en una carta del 30 de enero de 1937 dirigida a Mrs. Betty Barnes, mujer del corresponsal Joseph Barnes, dice lo siguiente:

$\mathrm{Me}$, I am going to Spain with the boys. I don't know who the boys are, but I am going with them. I feel out of everything and I would like to organize a column, called the Martha Ellis' column. Perhaps a column of nautch girls is what they need in Spain, they have about everything else. I daresay one can't walk in Madrid for tripping over Great Writers, also debris (citado en Moorehead 2006: 48-49).

Martha Gellhorn volverá a Barcelona en 1938, como informa en sus cartas a Mrs. Roosevelt, a quien le cuenta los ataques sobre Bilbao, los aviones alemanes que bombardean la ciudad catalana, y su orgullo por la mitad de los hombres que sobreviven de la Brigada Lincoln-Washington:

My plans are uncertain. I am staying to see what happen next. Things look fine now, the Fascists are directing their attack on the other half of Spain [...] What goes on here seems to me very much the affair of all of us, who do not want a world 
whose bible is Mein Kampf. I believe now as much as ever that Spain is fighting our battle, and will not forget that night when we brought the film to the White House and the President said: Spain is a vicarious sacrifice for all of us... But I think Spain is maybe not a sacrifice, but a champion: and hope to God that America at least will not go on letting this country down (citado en Moorehead 2006: 60).

Muchos años después, en 1960, en una carta dirigida al novelista neoyorquino Alvah Bessie, antiguo combatiente de las Brigadas Internacionales y autor del libro Men in Battle (1939), recuerda esos momentos de otra forma:

Spain will rise again but not for a very long time and perhaps neither in the way you expect not for reasons you would accept. It will also fall. This happens, dammit. I am glad, and will be glad all my life to have been young and there, at that time; I think we got something out of history that is more than anyone has a decent right to hope for. We got that fusion, so often attributed to the human body (but so rarely achieved except in literature) of body and soul; of living one's life and believing with one's whole heart in the life around one. Very special, I can tell you (citado en Moorehead 2006: 273).

\section{CONCLUSIÓN}

Se podría establecer una analogía entre la evolución que experimenta la crítica del relato de viajes con el contraste hallado entre estas dos viajeras. Desde la queja por la falta de atención a estas autoras y sus textos hasta la focalización en determinados aspectos, su actitud y ese espacio propio que cada una conforma. Se produce un cambio evidente en la actitud que adoptan ante el espejo de lo desconocido, al cruzar el umbral físico de los Pirineos, de otra cultura, y de su propio espacio como periodistas o corresponsales. En el primer caso, de Kate Field, y a pesar de ser, como demuestra durante toda su vida, muy independiente de las limitaciones sociales de su ambiente, sigue aún la tendencia de algunos de sus colegas. Con actitud crítica continúa mostrando sus prejuicios por una cultura cuya conquista histórica de su propio país no logra comprender. Atrás han quedado las descripciones exóticas y románticas de Irving, al que menciona en su obra, para quedarse tan solo con su reproche sobre la ciudad de Madrid y su situación geográfica. Como afirma Barbara Korte, "women, generally lacking access to political, administrative, and scholarly structures, tended to claim authority and value for their travel texts by emphasising the epistemological value of the subjective experience» (2000: 53). En este caso sí tienen acceso a la política, a pesar de lo cual, enfatizan su propia experiencia y su voz, tal vez para destacar entre las numerosas obras que aparecen en ese momento, como también harían sus colegas españolas, Eva Canel, Emilia Pardo Bazán o Carmen de Burgos. Martha Gellhorn, en cambio, dispone ya de una identidad propia, aunque aconsejada por ese amigo sin nombre, que ella menciona y al que tenemos hoy que agradecer dicho consejo. Con ironía, aplomo y sentido práctico ofrece una visión muy humana, casi fotográfica, de la rutina en tiempos de guerra, un uso diferente y nuevo del espacio, una "geografía» en un momento crítico que 
ella consigue transformar en algo rutinario, incluso bello, muy al contrario de lo que hiciera su colega Kate Field.

Ambas autoras consiguen crear ese espacio propio desde el que ver al otro, un espacio más reducido, desde el que compararse, no tan idealizado, ni tan exótico, y sí más real, más cercano, más auténtico. A pesar de las dificultades que experimentan ambas por ejercer su profesión periodística, poco considerada en esos momentos, «sometimes, the crossing of a threshold may result in just the opposite of marginality: acclaim and positive public recognition for the women concerned" (Gómez Reus \& Gifford 2013: 6). En ambos casos, es casualmente el viaje a la Península lo que actúa como catalizador, lo que propulsa la carrera periodística de estas dos incansables escritoras comprometidas con dar testimonio - cada una desde su propio espacio- de momentos cruciales de la historia de España.

Recibido: junio de 2018; ACEPTADo: octubre de 2018. 


\section{BIBLIOGRAFÍA}

Clarke, Robert (2018): The Cambridge Companion to Postcolonial Travel Writing, Cambridge: Cambridge University Press.

Creswell, Tim (2015): Place: an Introduction, $2^{\text {nd }}$ edition, Oxford: Wiley Blackwell.

Dixon, Ella Hepworth (1930): As I Knew Them: Sketches of Those I Have Met Along the Way, London: Hutchinson.

Fehlbaum, Valérie (2013): «Stepping Out: 'At Home' or 'From our Own Correspondent'? The Lady Writer or the Woman Journalist?», en Teresa Gomez Reus y Terry Gifford (eds.), Women in Transit through Literary Liminal Spaces, Basingstoke and New York: Palgrave Macmillan, 61-73.

Fenlbaum, Valérie (2017) [2005]: Ella Hepworth Dixon: The Story of a Modern Woman, London and New York: Routledge.

FIeld, Kate (1875): Ten Days in Spain, Boston: James R. Osgood \& Company.

Gellhorn, Martha (1988) [1959]: The Face of War, New York: Atlantic Monthly Press.

Gómez Reus, Teresa y Terry Gifford (eds.) (2013): «Introduction», en Teresa Gómez Reus y Terry Gifford, Women in Transit Through Literary Liminal Spaces, New York: Palgrave Macmillan, 1-14.

Kelley, Joyce (2005): «Increasingly 'Imaginative Geographies': Excursions into Otherness, Fantasy, and Modernism in Early Twentieth Century Women's Travel Writing», Journal of Narrative Theory 35 (3): 357-372.

Korte, Barbara (2000): English Travel Writing: From Pilgrimages to Postcolonial Explorations, Basingstoke and London: Macmillan.

Moorehead, Caroline (ed.) (2006): Selected Letters of Martha Gellhorn, New York: Henry Holt and Company.

Nardin, Jane (1997): «Kate Field on Two Continents», Papers on Language \& Literature 33 (4): 438-440.

Oliveira Martins, Isabel (2013): «The Representation of Otherness: an American Vassar Girl's Perspective on Spain», en Montserrat Cots, Pere Gifra-Adroher y Glyn Hambrook (eds.), Interrogating Gazes. Comparative Critical Views on the Representation of Foreignness and Otherness, Bern: Peter Lang, 179-186.

Pratt, Mary L. (1992): Imperial Eyes, Travel Writing and Transculturation, New York: Routledge.

Scharnhorst, Gary (2008): Kate Field, The Many Lives of a Nineteenth-century American Journalist, Syracuse: Syracuse University Press.

Schriber, Mary S. (1995): Telling Travels: Selected Writings by Nineteenth-century American Women Abroad, Dekalb: Northern Illinois University Press.

Serrano, M. ${ }^{a}$ del Mar (1993): Viajes de papel, (repertorio bibliográfico de guias y libros de viajes por España 1800-1921), Barcelona: Publicacions Universitat de Barcelona.

Simón Palmer, M. ${ }^{a}$ del Carmen (1991): Escritoras españolas del siglo XIX, Madrid: Castalia.

Wegner, Phillip E. (2002): «Spatial Criticism: Critical Geography, Space, Place, and Textuality», en Julien Wolfreys (ed.), Introducing Criticism at the 21 $1^{\text {st }}$ Century, Edinburgh: Edinburgh University Press, 179-201. 
Whiting, Lilian (1899): Kate Field, a Record, Boston: Little, Brown, and Company.

Woodward, Helen B. (1971): The Bold Women, New York: Books for Libraries Press.

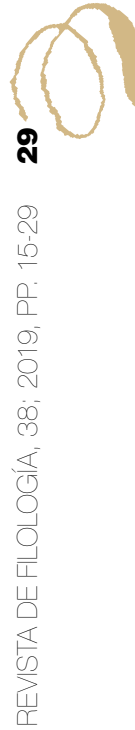


